\title{
Effectiveness Assessment of Investments in Robotic Biological Plant Protection
}

\author{
Tatiana Kudryavtseva ${ }^{1 *}$, Angi Skhvediani ${ }^{1}$ \\ ${ }^{1}$ Graduate School of Industrial Economics, Peter the Great St. Petersburg Polytechnic University, Saint \\ Petersburg 195251, Russia
}

\begin{abstract}
Evaluation of the effectiveness of digital technologies adoption is relevant in all areas of activity, including agriculture. The goal of this study is to evaluate the effectiveness of investments in robotic technologies for biological plant protection in greenhouse enterprises. This article proposes a decision-making algorithm for evaluating the effectiveness of investments in robotic technology projects for biological plant protection based on a financial model, which is supplemented by the technical and economic parameters of digital technologies. Testing of the model on the example of a Russian enterprise showed that the project pays off in two years, while the profitability of the enterprise grows by increasing the yield and boosting the sales of environmentally friendly products in the context of replacing chemical plant protection with biological methods. The main assessed risk factors for the project are a decrease in revenue, an increase in overall costs of the greenhouse, and an increase in the cost of digital technology development and implementation. Sensitivity of the project to personnel recruitment and requalification issues appeared to be very low. The study contributes to the development of methods for economic assessment of the effectiveness of digital technologies in agriculture. In addition, it shows in a specific case that for transitional and low-income countries (in this case Russia), implementation of the high technologies may result in higher relative operational expenses.
\end{abstract}

Keywords: Entomophagy; Fertilizer; Insectivore; Internet of things; Risks; Sensitivity analysis

\section{Introduction}

The digital economy is a system of economic relations in which data is a key factor in production in all fields (Rodionov and Rudskaia, 2018; Schepinin and Bataev, 2019). The transition to digital agriculture is closely linked to the processes that are transforming this area (Tang et al., 2002; Zaytsev, 2020). These processes imply the interaction of all components (agronomic, economic, financial, environmental, etc.), each of which is responsible for its own sphere (Ansari et al., 2016; Kovács and Husti, 2018; Zaborovskaya et al., 2019; Ciruela-Lorenzo et al., 2020). The transition to the digital economy of agriculture implies the formation and introduction of new structures and technologies that will ensure the development of the agricultural complex of the Russian Federation (Kurbatova et al., 2019; Panetto et al., 2020). Thus, in order to develop digital agricultural technologies, it is necessary to determine what data needs to be collected and processed to create a decision-making support system for agrarians. Based on this information, it is

${ }^{*}$ Corresponding author's email: kudryavtseva_tyu@spbstu.ru, Tel.: +7-812-534-73-31 doi: 10.14716/ijtech.v11i8.4528 
possible to determine the technical task for the formation of a digital solution and assess the economic efficiency of its realization.

To date, there are two main reasons for the digitization of the agricultural sector:

- Improving productivity of agro-industrial complex (AIC) sector enterprises;

- Reducing losses in agricultural production.

Losses in agriculture arise from natural conditions that the producer cannot affect, biological threats, and unskilled workers who fail to accept or use high-tech solutions (Trisasongko et al., 2016; Zinchenko, 2017; Wegren et al., 2019; Borisov and Danilova, 2020). Therefore, one of the potential economic effects of the digitization of the AIC in Russia can be an increase in the market supply of agricultural products.

Table 1 Possibilities, limitations and risks of digital technologies application in agriculture in Russia

\begin{tabular}{|c|c|c|}
\hline $\begin{array}{l}\text { Parame- } \\
\text { ters analyzed }\end{array}$ & Crop farming & Livestock farming \\
\hline $\begin{array}{l}\text { Systems and } \\
\text { technologies that } \\
\text { can be used in the } \\
\text { development of } \\
\text { digital solutions for } \\
\text { the AIC }\end{array}$ & $\begin{array}{l}\text { Precision farming systems; } \\
\text { GLONASS; } \\
\text { Satellite technologies; } \\
\text { Landscape maps; } \\
\text { Determining the actual acreage; } \\
\text { Predicting harvest yield and loss of } \\
\text { harvest; } \\
\text { Computer vision for planting } \\
\text { analysis; } \\
\text { Crop health monitoring; } \\
\text { Automatic watering systems. }\end{array}$ & $\begin{array}{l}\text { Machine vision for livestock accounting; } \\
\text { Facial recognition systems for livestock; } \\
\text { Forming animal diet; } \\
\text { Veterinary care; } \\
\text { Optimization of the agricultural } \\
\text { equipment park; }\end{array}$ \\
\hline \multirow{5}{*}{$\begin{array}{l}\text { Limitations and } \\
\text { risks of the } \\
\text { implementation and } \\
\text { use of digital } \\
\text { solutions for the AIC }\end{array}$} & \multicolumn{2}{|c|}{$\begin{array}{l}\text { The need to carry out a large amount of research and development to refine the } \\
\text { technologies used in the final product, including the development of the user } \\
\text { interface and solutions for the integration of various technical and information } \\
\text { systems. }\end{array}$} \\
\hline & \multicolumn{2}{|c|}{$\begin{array}{l}\text { The need to train new highly qualified personnel and retrain existing ones, } \\
\text { including in the skills of organization, processing, and analyzing digitally } \\
\text { generated information }\end{array}$} \\
\hline & \multicolumn{2}{|c|}{$\begin{array}{l}\text { The need to develop new standards for agricultural activities, taking into } \\
\text { account the use of digital solutions }\end{array}$} \\
\hline & \multicolumn{2}{|c|}{ Low level of development of telecommunications infrastructure in rural areas } \\
\hline & $\begin{array}{l}\text { Restrictions on aerial photography } \\
\text { data }\end{array}$ & $\begin{array}{l}\text { Need to import modern technological } \\
\text { means of keeping, feeding, and taking } \\
\text { care of animals }\end{array}$ \\
\hline
\end{tabular}

Table 1 organizes the main areas of digital use in agriculture, as well as the main limitations and risks of their application in Russia. These limitations and risks are based on a literature review of the results of the theory and practice of the introduction of digital solutions in agriculture of other countries, including developing countries such as Russia. Among the main constraints, we should point out the significant need for investments related to production facilities and infrastructure upgrades (Lele and Goswami, 2017; Pivoto et al., 2018; Iovlev et al., 2019; Zaytsev, 2020), the requalification and training of staff capable of working with new technologies (Salemink et al., 2017; Pivoto et al., 2018; Rotz et al., 2019; Kudryavtseva et al., 2019), the difficulties in purchasing technologies and 
equipment abroad, and the inaccessibility of information (Yong et al., 2018). These limitations create significant risks for the successful implementation of projects applying digital solutions in agriculture and their increase in price.

Within the current study, the object of research is the use of robotic technologies to carry out the protection of plants using biological methods. Table 2 presents some of the latest developments used in plant protection. The equipment described in Table 2 is usually designed either for spraying (chemical protection of plants) or for pruning and thinning. In addition, we present robots engaged in biological plant protection in one way or another and mention the use of drones for scanning the territory and producing a detailed map of the state of the fields. With additional software, such drones can identify the contamination zones in the greenhouse area. The authors found the only robot on the market that can conduct both pest treatment and pruning, LettuceBot2. However, this robot cannot be used in greenhouse farms for biological plant protection. Thus, the authors were not able to find robotic solutions capable of scanning the territory of greenhouses for infestation with insect pests and placing biological agents of protection (entomophages) automatically.

Table 2 Robots used for biological plant protection

\begin{tabular}{|c|c|}
\hline Machine & Functions \\
\hline LettuceBot2 (2nd generation) & thinning and spraying; pruning \\
\hline Agribotix Hornet Drone & $\begin{array}{l}\text { producing high-resolution images and maps using a variety } \\
\text { of sensors and their processing; map processing to reveal } \\
\text { which locations are most in need of fertilizer and protection }\end{array}$ \\
\hline Wall-Ye 1000 mobile & pruning \\
\hline Grizzly RUV & $\begin{array}{l}\text { detecting stems and their trimming inside the soil using a } \\
\text { laser scanner; tillage }\end{array}$ \\
\hline Forge Robotic Platform & pruning and spraying \\
\hline $\begin{array}{l}\text { Development of Wageningen UR and } \\
\text { Agritronics, Sint Annaparochie }\end{array}$ & spraying (point and hinged) \\
\hline Precision Hawk development & providing data on the status of the territory to agronomists \\
\hline SenseFly development & territory analysis and compilation of a detailed map \\
\hline FLYSEEAGRO & multi-spectrum field photography \\
\hline
\end{tabular}

Because of increasing interest in and attention to ecology and health, agricultural enterprises need to address the challenge of improving the environmental safety of production. Despite the simplicity of using chemical methods to protect plants inside greenhouses, enterprises are faced with a number of negative consequences, which are difficult to measure: harm to human health (both workers and consumers) and harm to treated soil. Separately, we should note the increasing costs of creating or acquiring new chemicals due to the adaptation of pests to the chemicals used, as well as the growth of the exchange rates of major currencies against the ruble.

Many countries in Europe are currently switching or have already switched to biological methods of plant protection, although this method also has a number of drawbacks. Among the drawbacks is its slow action, so there is a need for constant monitoring of the condition of the greenhouse, which requires having specialized workers on staff.

The goal of this research is to assess the cost-effectiveness of robotic technology for biological plant protection. To achieve this goal, feasibility studies of the project will be considered, a comparative analysis of costs will be carried out, and the effectiveness of investments in robotic technology of biological protection of greenhouse plants located in the Moscow region of Russia, as well as the risks of the project will be assessed. 


\section{Methods and Project Description}

\subsection{Project Description}

The project of robotic biological plant protection implementation is a perspective project, which was developed on demand for the Podosinki greenhouse complex, located in Moscow Oblast in the Russian Federation. This greenhouse complex was built in collaboration with the Dutch companies Bulneth and Dalsem Horticultural Projects B.V. This complex includes three greenhouses covering 3 hectares (ha) each. Financial data and other information, which is used for assessment of project effectiveness, was gathered from this enterprise. In accordance with the specifications of this project, a solution for robotic plant protection that satisfies the following requirements can be offered:

- "Green" biological protection, that is, pests are destroyed by entomophages;

- Robotic technologies based on computer vision, which will automate the process of analyzing the state of plants and introducing entomophages.

Plant protection by biological methods means the use of entomophages and biologics to control pests and plant diseases in greenhouses. This method prevents the problem of pest resistance arising from the use of traditional chemical methods of pest control.

The second part of the proposed technology consists of a technical vision algorithm that detects plant contamination at an earlier stage than traditional methods. This component implies continuous monitoring of the growth and development of greenhouse plants. If insect pests or diseases are revealed, the introduction of protective biologics and entomophages occurs. Traditional methods of plant protection, which are used at the Podosinki greenhouse, assume that one agronomist should monitor the phytosanitary conditions at one greenhouse with an area of 1 ha. Therefore, this agronomist can perform only one round check per eight hours of work. The project assumes that a robot will be able to perform 10 rounds of checks in 24 hours. Such a high frequency of checks will allow for the identification of micro-outbreaks of pests and sicknesses, which should increase the effectiveness of biological protection. Therefore, the main advantage of this project is early detection of micro outbreaks of pests and sicknesses, which means that the greenhouse operator can use less aggressive means to deal with. This approach provides increased accuracy over human actions and contributes to higher crop quality and lower wage expenses.

\subsection{Method of the Research}

In order to assess the effectiveness of the proposed project, we developed an algorithm, which is presented in Figure 1. The proposed algorithm consists of four main steps.

First, we compare the costs of traditional methods of plant protection and the estimated costs of alternative methods. In the current paper, we compare the costs of pesticide usage and an unskilled workforce against those of using robotic biological plant protection.

Next, we determine the key parameters of the alternative method. Based on many years of research on the rationale for using biological protection methods, it is concluded that using these methods it is possible to obtain $70-100 \%$ of the harvest. However, it should be understood that when switching to this method of plant protection, it makes no sense to expect immediate results. This method of protection requires constant monitoring of plant conditions and forecasting the development of pests, which calls for a high level of technological complexity. In our case, according to the project specifications, one robot can cover 1 ha of the greenhouse. One technical specialist should be hired to maintain the robots. 
After that, we build the financial model of the project, calculate its net present value (NPV), and evaluate risks. Indicators for risk assessment are chosen based on the results of risk systematization, presented in Table 1 of the introduction. Namely, we suggest measuring risks using costs (overall increase in costs as a result, for example, of a pest outbreak and loss of the product), price of technology (under- or overestimation of the investment costs for robot development), revenue (under- or overestimation of the forecasted company revenues), and wages of production personnel (under- or overestimation of size and salaries of the highly qualified personnel who should be employed after robot introduction).

\begin{tabular}{|l|l|}
\hline $\begin{array}{l}\text { 1. Comparison of costs for the } \\
\text { traditional and robotic protection } \\
\text { methods }\end{array}$ & $\begin{array}{l}\text {-allocation of costs for: wages of workers engaged in plant } \\
\text { protection; means of protection; depreciation of equipment; } \\
\text {-analysis of results of activities during application of different } \\
\text { protection methods; }\end{array}$ \\
\hline \begin{tabular}{|l|l|} 
2. Parameters of the digital technology \\
project
\end{tabular} & $\begin{array}{l}\text {-1 robot per } 1 \text { ha; } \\
\text {-provision of a technical specialist; } \\
\text { - increasing protection productivity to } 10 \text { times compared to } \\
\text { the one achieved by an agronomist; }\end{array}$ \\
\hline 4. Sensitivity analysis & $\begin{array}{l}\text { - determination of the project discount rate; } \\
\text { - calculation of the project NPV; }\end{array}$ \\
\hline $\begin{array}{l}\text { - selection of indicators: revenue; technology price; cost price; } \\
\text { wages of plant protection workers; } \\
\text { - evaluation of influence of the selected indicators on the } \\
\text { investment project NPV }\end{array}$ \\
\hline
\end{tabular}

Figure 1 Decision-making algorithm for investments in digital technologies

The proposed decision-making algorithm will allow agricultural enterprises to decide on the effectiveness of the introduction of robotic plant protection technology.

\section{Results}

The costs, efficiency, and risks of the robotic biological plant protection technology project are assessed on an example of Podosinki greenhouse complex.

Table 3 shows how the cost structure changes for the plant protection methods evaluated in this paper. Attention should be paid to the decrease in the share of wages of workers employed in the process of plant protection from $12.36 \%$ to $11.94 \%$. The small difference in the cost of biological protection agents and chemicals makes these costs relatively equal. Also, special attention should be paid to the growth, from $0.26 \%$ to $1.76 \%$, of the equipment depreciation costs. Although more equipment is used, the overall cost of chemical plant protection is less than that of robotic biological plant protection.

Table 4 shows a comparison of the results of greenhouse farming when using the two protection methods.

The increase in revenue is due to a $17.5 \%$ average increase in yields using robotic biological plant protection. Based on the results presented in Table 4, we can once again see that the cost of production increases with the use of robotic biological plant protection, but its share in the revenue is reduced, which leads to an increase in profitability from $13.21 \%$ to $24.75 \%$. 
Table 3 Comparison of greenhouse cost structures for chemical and biological plant protection

\begin{tabular}{|c|c|c|c|c|}
\hline \multirow[b]{2}{*}{ Cost structure } & \multicolumn{2}{|c|}{ Chemical method } & \multicolumn{2}{|c|}{ Robotic biological method } \\
\hline & $\begin{array}{c}\text { Average } \\
\text { absolute costs, } \mathrm{P} \\
\text { per } \mathrm{m}^{2} \text { per } \\
\text { month }\end{array}$ & $\begin{array}{l}\text { Percentage of } \\
\text { total costs, } \%\end{array}$ & $\begin{array}{l}\text { Average absolute } \\
\text { costs, P per } \mathrm{m}^{2} \text { per } \\
\text { month }\end{array}$ & $\begin{array}{l}\text { Percentage of } \\
\text { total costs, } \%\end{array}$ \\
\hline Wages and deductions & 58.63 & 12.36 & 57.68 & 11.94 \\
\hline $\begin{array}{l}\text { including wages and deductions } \\
\text { of workers involved in the } \\
\text { protection of plants }\end{array}$ & 10.69 & 2.25 & 9.74 & 2.02 \\
\hline Fertilizers & 51.97 & 10.96 & 51.97 & 10.76 \\
\hline Means of protection & 6.03 & 1.27 & 7.21 & 1.49 \\
\hline Heating & 52.00 & 10.96 & 52.00 & 10.76 \\
\hline Electricity & 29.00 & 6.11 & 29.00 & 6.00 \\
\hline Water supply & 19.62 & 4.14 & 19.62 & 4.06 \\
\hline Amortization of equipment & 1.23 & 0.26 & 8.49 & 1.76 \\
\hline including treatment & 0.29 & 0.06 & 7.56 & 1.56 \\
\hline Seeds & 70.60 & 14.88 & 70.60 & 14.61 \\
\hline Fuels and lubricants & 0.88 & 0.19 & 0.65 & 0.13 \\
\hline Other expenses & 18.82 & 3.97 & 20.45 & 4.23 \\
\hline Management expenses & 165.54 & 34.90 & 165.54 & 34.26 \\
\hline Total & 474.31 & 100 & 483.21 & 100 \\
\hline
\end{tabular}

Biological agents are more expensive than chemicals, but the difference in cost is small, and the share of both approaches in the cost structure is roughly similar. However, the labor costs associated with robotic biological plant protection has fallen significantly despite requiring new specialist workers. A decrease in this line in the cost system is associated with a decrease in the number of unskilled workers. A significant increase in costs is observed for depreciation of equipment, which is due to the higher cost of robotic technologies.

Based on the analysis of cash flows within the project, the project's financial model was built, taking revenue growth as a result of higher yields and increased costs for wages and plant protection into account. The total investment of the 9-hectare greenhouse farm amounted to 42194 thousand rubles or 4.6 thousand rubles per square meter. The project's performance indicators are presented in Table 5. Further, we have analyzed the sensitivity of the project indicators to basic parameters such as cost, price of technology, revenue, and salaries of production personnel. Figure 2 demonstrates the results of this analysis.

Table 4 Comparison of greenhouse enterprise results structures for chemical and biological plant protection

\begin{tabular}{|c|c|c|c|c|}
\hline \multirow{2}{*}{$\begin{array}{r}\text { Indicators when using } \\
\text { different } \\
\text { plant } \\
\text { protection } \\
\text { methods }\end{array}$} & \multicolumn{2}{|c|}{ Chemical method } & \multicolumn{2}{|c|}{ Robotic biological method } \\
\hline & $\begin{array}{l}\text { Average absolute } \\
\text { figures, P per } \mathrm{m}^{2} \\
\text { per month }\end{array}$ & $\begin{array}{l}\text { Percentage of } \\
\text { total costs, } \%\end{array}$ & $\begin{array}{l}\text { Average absolute } \\
\text { figures, P per } \text { m² }^{2} \text { per } \\
\text { month }\end{array}$ & $\begin{array}{c}\text { Percentage of total } \\
\text { costs, } \%\end{array}$ \\
\hline \multicolumn{5}{|l|}{ Indicators } \\
\hline Revenue & 546.48 & 100 & 642.12 & 100 \\
\hline Cost of sales & 260.83 & 47.73 & 269.73 & 42.01 \\
\hline Gross profit & 285.65 & 52.27 & 372.38 & 57.99 \\
\hline Management expenses & 213.48 & 39.06 & 213.48 & 33.25 \\
\hline Profit from sales & 72.17 & 13.21 & 158.90 & 24.75 \\
\hline
\end{tabular}


Table 5 Performance indicators of the 9-hectare greenhouse biological plant protection project

\begin{tabular}{lcc}
\hline \multicolumn{1}{c}{ Indicators } & Measurement units & Value \\
\hline NPV (Net Present Value) & thousand rubles & 9371.36 \\
PI (Profitability Index) & coefficient & 1.23 \\
IRR (Internal Rate of Return) & $\%$ & 39.82 \\
ROI (Return on Investment) & $\%$ & 161.39 \\
PB (Payback Period) & years & 2 \\
\hline
\end{tabular}

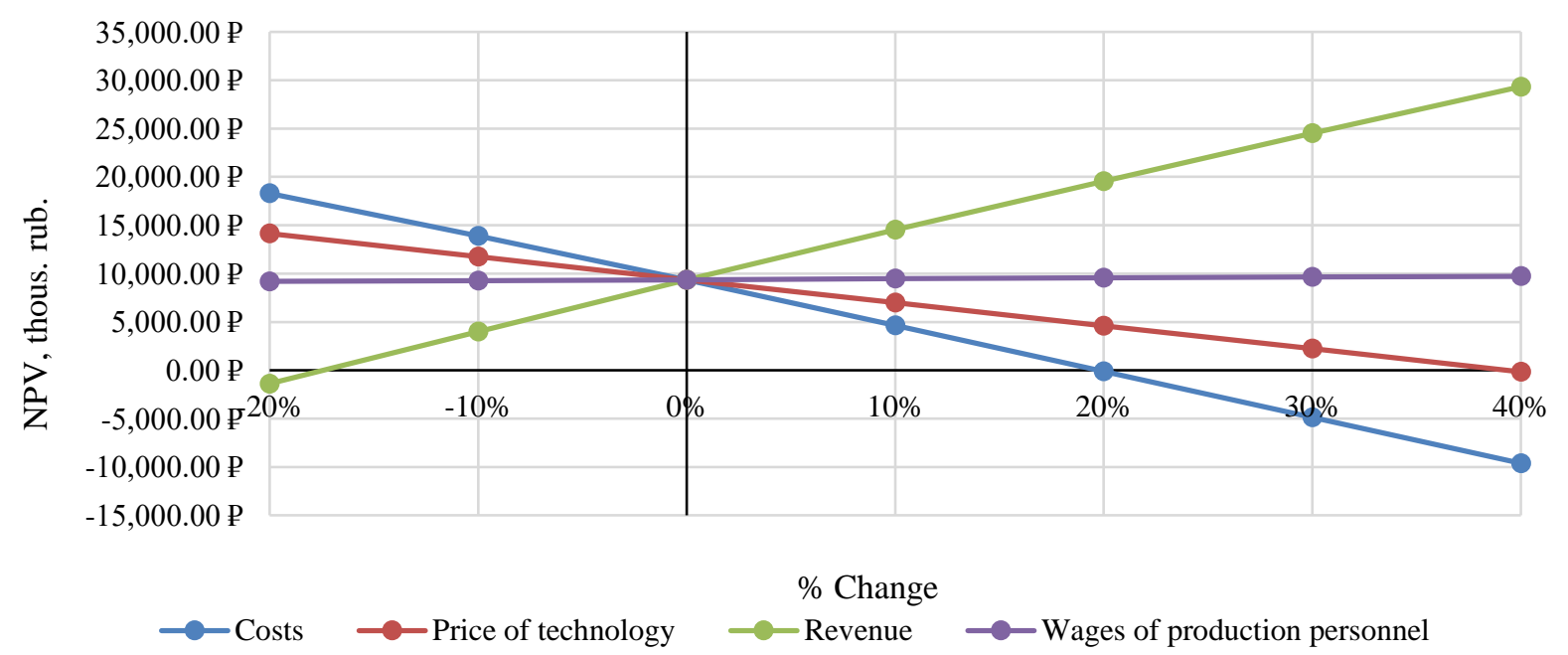

Figure 2 Sensitivity of the NPV indicator to changes in selected indicators

The resulting indicators of the investment project are sensitive to changes in the revenue and the price of technology. With the $40 \%$ increase in the cost of robotic technologies, this investment project loses its relevance for the company. With the $20 \%$ reduction in revenue, the project NPV becomes negative.

Based on the calculations, it can be concluded that the introduction of robotic biological technologies increases the efficiency of the agricultural enterprise by increasing the revenue as a result of higher yields, as well as increasing consumer demand because the products are grown without the use of chemicals.

\section{Discussion}

The introduction of robotic technology for biological plant protection makes it possible to increase the efficiency of enterprises in the AIC as a result of reducing losses during agricultural production and increasing its safety. However, according to the results of the study, agriculture carries great financial risks, such as the rising price of robotic technology, especially in the case of supplements imports (Yong et al., 2018). Another risk is decreased revenue, which may be due to a decrease in the purchasing power of the population or oversupply in the market. In addition, robotic biological protection requires higher costs per square meter per month, compared to traditional methods of plant protection. Basically, this means that the relative costs can become higher after high technology implementation in transitional or low-income countries. This effect is based on the idea that since the price of maintenance of these technologies and their usage is higher, then the company should receive more added value from their usage and convert it in higher returns to the company, which cannot always be possible in transitional or low-income countries. Also, we should note that the project is not sensitive to the costs of training and hiring highly qualified staff (Salemink et al., 2017; Pivoto et al., 2018; Rotz et al., 2019). 


\section{Conclusions}

The study proposed and tested a decision-making algorithm for investments in robotic technologies of biological plant protection. The proposed decision-making algorithm will allow agricultural enterprises to make decisions on the effectiveness of investments in robotic plant protection technology projects. At the heart of the algorithm lies the financial model, which is supplemented by the technical and economic parameters of digital technology.

As a result of the study, it has been proven that the introduction of robotic biological plant protection technology improves the profitability of the agricultural enterprise; this investment pays off in two years. The project is most sensitive to such factors as a decrease in revenue for eco-products and an increase in the cost of robotic technology considering scientific and technical uncertainty in the use and creation of new technology and an increase in overall costs.

An important limitation of this study is that it was modeled on one greenhouse farm located in Russia. As part of the following detailed research, the algorithm is being tested at agricultural enterprises in other regions.

\section{Acknowledgements}

This research was supported by the Academic Excellence Project 5-100, proposed by Peter the Great St. Petersburg Polytechnic University.

\section{References}

Ansari, M.T., Armaghan, N., Ghasemi, J., 2016. Barriers and Solutions to Commercialization of Research Findings in Schools of Agriculture in Iran: A Qualitative Approach. International Journal of Technology, Volume 7(1), pp. 5-14

Borisov, A.I., Danilova, S.S., 2020. Current Russian Agricultural Development Trends. IOP Conference Series: Earth and Environmental Science, IOP Publishing, 22031

Ciruela-Lorenzo, A.M., Del-Aguila-Obra, A.R., Padilla-Meléndez, A., Plaza-Angulo, J.J., 2020. Digitalization of Agri-Cooperatives in the Smart Agriculture Context. Proposal of a Digital Diagnosis Tool. Sustainability, Volume 12(4), pp. 1-15

Iovlev, G.A., Saakian, M.K., Goldina, I.I., Nesgovorov, A.G., 2019. The Role of Digitalization of Technological Service in Increasing Efficiency of Agricultural Production. Agrarian Education and Science, Volume 2, p. 8

Kovács, I., Husti, I., 2018. The Role of Digitalization in the Agricultural 4.0-How to Connect the Industry 4.0 to Agriculture? Hungarian Agricultural Engineering, Volume 33, pp. $38-42$

Kudryavtseva, T., Skhvediani, A., Arteeva, V., 2019. Theoretical Analysis on the Effect of Digitalization on the Labor Market. In: European Conference on Knowledge Management, pp. 672-679

Kurbatova, S.M., Aisner, L.Y., Naumkina V.V., 2019. Some Aspects of the Essence and Legal Regulation of Agriculture Digitalization as One of the Priorities of Modern State Policy of Agriculture Development. IOP Conference Series: Earth and Environmental Science, IOP Publishing, 32021

Lele, U., Goswami, S., 2017. The Fourth Industrial Revolution, Agricultural and Rural Innovation, and Implications for Public Policy and Investments: A Case of India. Agricultural Economics, Volume 48(S1), pp. 87-100 
Panetto, H., Lezoche, M., Hernandez, J., Diaz, M.Del M.E.A., Kacprzyk, J., 2020. Special Issue on Agri-Food 4.0 and Digitalization in Agriculture Supply Chains-New Directions, Challenges and Applications. Computers in Industry, Volume 116(103188)

Pivoto, D., Waquil, P.D., Talamini, E., Finocchio, C.P.S., Corte, V.F.D., Mores, G.De.V., 2018. Scientific Development of Smart Farming Technologies and Their Application in Brazil. Information Processing in Agriculture, Volume 5(1), pp. 21-32

Rodionov, D., Rudskaia, I., 2018. Problems of Infrastructural Development of 'Industry 4.0' in Russia on Sibur Experience. In: Proceedings of the 32nd International Business Information Management Association Conference, IBIMA 2018 - Vision 2020: Sustainable Economic Development and Application of Innovation Management from Regional Expansion to Global Growth, pp. 3534-3544

Rotz, S., Gravely, E., Mosby, I., Duncan, E., Finnis, E., Horgan, M., LeBlanc, J., Martin, R., Neufeld, H.T., Nixon, A., Pant, L., Shalla, V., Fraser, E., 2019. Automated Pastures and the Digital Divide: How Agricultural Technologies are Shaping Labour and Rural Communities. Journal of Rural Studies, Volume 68, pp. 112-122

Salemink, K., Strijker, D., Bosworth, G., 2017. Rural Development in the Digital Age: A Systematic Literature Review on Unequal ICT Availability, Adoption, and Use in Rural Areas. Journal of Rural Studies, Volume 54, pp. 360-371

Schepinin, V., Bataev, A., 2019. Digitalization of Financial Sphere: Challenger Banks Efficiency Estimation. IOP Conference Series: Materials Science and Engineering, 012051

Tang, S., Zhu, Q., Zhou, X., Shaomin, L., Wu, M., 2002. A Conception of Digital Agriculture. IEEE International Geoscience and Remote Sensing Symposium, IEEE, 3026-3028

Trisasongko, B.H., Panuju, D.R., Harimurti Ramly, A.F., Subroto, H., 2016. Rapid Assessment of Agriculture Vulnerability to Drought using GIS. International Journal of Technology, Volume 7(1), pp. 114-122

Wegren, S.K., Nikulin, A.M., Trotsuk, I., 2019. Russian Agriculture during Putin's Fourth Term: A SWOT Analysis. Post-Communist Economies, Volume 31(4), pp. 419-450

Yong, W., Shuaishuai, L., Li, L., Minzan, L., Ming, L., Arvanitis, K.G., Georgieva, Cs., Sigrimis, N., 2018. Smart Sensors from Ground to Cloud and Web Intelligence. IFACPapersOnLine, Volume 51(17), pp. 31-38

Zaborovskaya, O., Kudryavtseva, T., Zhogova, E., 2019. Examination of Mechanisms of Regional Sustainable Development Strategy as Exemplified by the Leningrad Region. International Journal of Engineering and Advanced Technology, Volume 9(1), pp. 50655076

Zaytsev, A., 2020. Rental Income Structure in Economy as a Basis for Sustainable Agrarian Relations in the Agro-Industrial Complex. Sustainability, Volume 12(18), pp. 1-20

Zinchenko, A.P., 2017. Studying the Problems of Economic Reproduction in Agriculture of Russia. Studies on Russian Economic Development, Volume 28, pp. 140-146 